\title{
Plural Voting and Representation of Minorities in Central Europe
}

\author{
Ágnes BALÁZS
}

\author{
Nemzeti Közszolgálati Egyetem, Államtudományi és Közigazgatási Kar \\ National University of Public Service, Faculty of Political Science and Public Administration \\ Ménesi út 5, 1118 Budapest, Hungary \\ balazsagnes@windowslive.com
}

\section{Introduction}

Suffrage played an important role in our region during the first half of the $20^{\text {th }}$ Century. Several electoral reforms were made and a lot of proposals were prepared during this time in Hungary. These reforms led to step-by-step broadening of suffrage and to general, equal suffrage, accordingly secret ballot voting. Plural voting means that some of the voters are entitled to cast multiple votes or some voters' votes weigh more than others', which means an exemption from the principle of equal suffrage. ${ }^{1}$ That seems to be imaginable today in a democratic state under the rule of law. Or maybe it is not? Plural voting was almost introduced in Hungary in 1907 and in 1938 it became real. In this paper we examine these two cases and the opinion of academics of this era dealing with public law or political science, with special regard to the proposal submitted in 1907. Before that we outline the process of broadening suffrage in Hungary since 1847. It will come to light whether plural voting is applicable nowadays or not, and how it is connected to national minorities. The question will be answered as well, whether plural voting could be connected to Hungary nowadays in the context of national minorities or not. First of all, we examine the forms of plural voting which were applied in Europe.

\section{Plural Voting in Europe in the $20^{\text {th }}$ Centrury}

According to Stefano Bartolini, plural voting existed not only in Austria (1861-1907), in Belgium (1893-1919) and in France (1820-1830), but also in Ireland (1815-1914 and 19181922/1936), in Sweden (to 1866) and in the United Kingdom (1866-1914 and 1918-1948) among European countries. ${ }^{2}$ The plural voting system of Belgium was introduced at the same time with the increase of the voters' number from 136,775 to $1,354,891$. The voters were divided into three electoral classes. Males who were at least twenty-five years old could cast one vote, but more wealthy voters were entitled to cast two or three votes. ${ }^{3}$ Men holding certain land property, accordingly men at least thirty years old, paying at least five frank taxes per year and having at least one legitimate child could cast two votes. Three 1 PAPP, Imre: A politikai részvételi jogok. in: Emberi jogok, TÓTH, Gábor - HALMAI, Attila (eds.), Budapest 2003, 750.

2 BARTOLINI, Stefano: The Political Mobilization of the European Left, 1860-1890. The Class Cleavage, New York 2000, 353.

3 GOLDSTEIN, Robert Justin: Political Repression in 19th Century Europe, London 1983, 27-33. 
votes could have been cast by men who were at least twenty-five years old, having certain level of education or holding certain offices. ${ }^{4}$ According to this system, 850 thousand men could cast one vote, 290 thousand could cast two and 22 thousand could vote three times. Dual voting existed in Russia (1905-1907) as well. These systems were aimed at the suppression of the several people belonging to lower classes and ensure the supremacy of higher classes. ${ }^{5}$

Luce wrote on a French proposal aimed at the establishment of the so-called "family suffrage". The prevention of further decrease of the population and ensuring that laws are adopted in the favour of family, the basic element of society, were the basis of this proposal. Heads of families could have cast various number of votes depending on the number of their children. ${ }^{6}$ He also turns the light to the fact that the Representation of People Act did not only contain rules ensuring plural voting, but it increased the number of voters who could cast multiple votes in the United Kingdom. Merely men having a higher level university degree could cast two votes before. From the time when the above mentioned Act entered into force, men having any level of university degree had two votes in the event they fulfilled the other criteria of suffrage. They could cast a vote as any voter and another one in the special university constituencies. ${ }^{7}$ According to Sándor Berecz there were 150 thousand voters having the right to cast multiple votes at this time in the United Kingdom. ${ }^{8}$ Plural voting was actually abolished in the United Kingdom only by the Representation of People Act 1948. Neither university votes existed any more, nor could the property owners' having property in a different constituency than their domicile belonged cast multiple votes any more. ${ }^{9}$ In the next section we will examine the broadening of suffrage in Hungary and the proposal of Gyula Andrássy.

\section{From the Establlishment of the Suffrage Ensuring Popular Representation towards Proposal of Gyula Andrássy}

The claim for broadening the suffrage and ensuring real popular representation despite representation based on the estates of the realm occurred during the $19^{\text {th }}$ Century in Hungary. The Opposition's Declaration of 1847, twelve points of the Hungarian Revolutioners of 1848 and Mihály Táncsics set the requirement of the establishment of popular representation as well. They were aimed at the establishment of popular representation with a low census or without a census. Act 5 of 1848 ensured popular representation but it lacked the rules realizing general suffrage. Several electoral reforms followed it, even new laws had been adopted. ${ }^{10}$ According to the Act 5 of 1848, voters were to meet certain income, pe-

4 LUCE, Robert: Legislative Principles: The History and the Theory of Lawmaking Representative Government, New Jersey 2007, 272.

5 GOLDSTEIN, 27-33.

6 LUCE, 272.

7 LUCE, 271-272.

8 BERECZ, Sándor: A tökéletes választójog, Budapest 1932, 38.

9 BARNETT, Hilarie: Constitutional \& Admininstrative Law, Abingdon 2013, 275; GRIFFITH, J.A.G: Representation of the People Act, 1949, in: The Modern Law Review, 13, 1950, 3, 48.

10 ÁCS, Nándor: A magyar választási rendszer főbb változásai 1848-től 1989-ig, in: Ünnepi tanulmányok Rácz 
cuniary and occupational censuses. Only Hungarian citizen men who were at least twenty years old were entitled to vote. A new electoral law was adopted in 1874. The proportion of people eligible to cast a vote decreased from $7.1 \%$ to $5.5 \%$ of the population. This law prescribed a taxation census instead of income census and excluded people holding certain offices from suffrage. After that, the electoral laws were not changed significantly until $1913 .{ }^{11}$ To summarize, at this time electoral censuses were stipulated in the law but no voters could cast multiple votes.

Plural voting was an emerging issue in the first half of the $20^{\text {th }}$ Century in Hungary. Gyula Andrássy submitted a bill connected to this institution as a minister of the interior in 1908. This bill had been surrounded by a huge dispute both in academic and public life until its withdrawal in 1909 and even after that. Mihály Réz, a public lawyer, university teacher and correspondent member of the Hungarian Academy of Sciences ${ }^{12}$ considered the supremacy of ethnic Hungarians in public life being a priority. In his point of view, the above mentioned bill was the one among all of the electoral proposals published which would have ensured this supremacy. According to him, plural voting would be the best institution to the mitigation of the general suffrage's disadvantageous effects, but not even that could ensure protection from all of the dangers. He shed light on the fact that ethnic Hungarians' proportion would be the highest among voters who could cast three votes $(71.7 \%)$. This proportion would have been less among voters having two votes $(63.3 \%)$ and the least among people having a single vote (58.6\%). Besides that, he proudly stated that people of the working class could cast 1,400,000 votes together instead of the 66 thousand votes they had at the time. ${ }^{13}$

He discloses some more details concerning the proposed rules of plural voting. All men would have had suffrage who were Hungarian citizens, at least twenty-four years old, have a permanent residence for at least one year, do not hold an office incompatible with suffrage, and were not excluded from suffrage. Men who finished at least four years of the secondary school; or had a job requiring such an education; furthermore, who accomplished military service and who were at least thirty-two years old; accordingly who had at least three legitimate children; furthermore who paying a tax of at least twenty Austro-Hungarian Korona; moreover employees working at the same employer since at least five years could have casted two votes. Men who finished the secondary school or working in a job requiring such an education, furthermore who pay one hundred Korona taxes could have casted three votes. Mihály Réz stated, that unequality based on the evaluation of work and performance is desirable concerning suffrage. He called it to a right form of an unequality. He considered public interest as the only measure of giving suffrage, and he thought that keeping the intelligentsia in power would be the main public interest. ${ }^{14} \mathrm{It}$ is important to note that Mihály Réz opposed general and equal suffrage accordingly secret ballot voting,

Attila 75. születésnapja tiszteletére, CSERNY Ákos (ed.), Budapest 2013, 23-25.

11 lbidem, 24-25.

12 Magyar Életrajzi Lexikon 1000-1990 - Réz Mihály, online: http://mek.oszk.hu/00300/00355/html/ ABC12527/12993.htm (Downloaded 18 March 2014).

13 RÉZ, Mihály: Gróf Andrássy választójogi tervezete, in: Választójog. Tanulmányok, TISZA István et.al., Budapest 1913, 80-81.

14 lbidem, 81-85. 
considering it as a definitely perilous institution to the ethnic Hungarians' supremacy. ${ }^{15}$ István Tisza agreed with the liberal politician Károly Hieronymi ${ }^{16}$ that plural voting is based on the assumption that the lower social groups' suffrage is a factor that endangers the national public interest. Both of them thought that (theoretically) it would be more honest not giving suffrage to all these groups at all, than creating an illusion of suffrage with the help of plural voting. István Tisza pointed it out at the same time that the coalition did not have any option but to adopt a law ensuring general suffrage. In that context he considered plural voting as the least wrong option, because there were no other means to the prevention of the "national disaster" deriving from the increase of the voter's number two and a half time higher than it was before. He thought that the number of plural votes guaranteed majority to the voters whom he considered as more educated, more mature and politically more trustworthy. In spite of that, he agreed with Károly Hieronymi that the condition of casting two or three votes had not been stipulated in an accurate way so it is not enough for the prevention of the "national disaster". ${ }^{17}$ The coalition could agree with the King only by promising that a new Parliament elected through fair elections would adopt a law ensuring general suffrage and secret ballot voting. They also had to promise that after all these, the parliament elected based on such a suffrage would decide on the disputed questions of the legal relation between Austria and Hungary. That is why the coalition did not have any other option but to introduce general suffrage. ${ }^{18}$

Dezső Márkus legal scientist, judge of a tribunal, legal writer and editor ${ }^{19}$ evaluated the broadening of suffrage as a positive measure, which is constitutionally acceptable. At the same time he did not agree with people who had been thinking that it would be the cure to all of the problems. He declared that in a state ensuring the equality of citizens by statutes, the violation of this equality by plural voting is impermissible. He stated that plural voting would make the suffrage of voters having one single vote insignificant. He considered that giving equal suffrage to voters would be axiomatic and based on the fundamental laws in effect. $^{20}$

Kálmán Molnár public lawyer, university teacher and correspondent member of the Hungarian Academy of Sciences ${ }^{21}$ wrote in the third edition of his textbook "Hungarian Public Law" about the proposal of Andrássy submitted in 1907 as well. He evaluated this bill as harmonizing national interest and the requirements of the "Zeitgeist". He referred to the "Tripartitum" of Werböczy 22 and declared that the plural voting is based on an an-

15 RÉZ, Mihály: A választói jogról, in: Választójog. Tanulmányok, TISZA István et.al., Budapest 1913, 73.

16 Magyar életrajzi lexikon 1000-1990 - Hieronymi Károly, online: http://mek.oszk.hu/00300/00355/html/ ABC05727/06328.htm (Downloaded 18 March 2014).

17 TISZA, István: Hieronymi a választójogról, in: Választójog. Tanulmányok, TISZA, István, et.al., Budapest 1913, $113-114$.

18 VÉRTES, István: 100 éves harc a választójogért, Budapest 1934, 99.

19 Magyar Életrajzi Lexikon 1000-1990 - Márkus Dezső, online: http://mek.oszk.hu/00300/00355/html/ ABC09732/10071.htm (Downloaded 18 March 2014).

20 MÁRKUS, Dezső: Választójog. A nő választójoga. Két tanulmány, Budapest 1912, 7, online: http://mtdaportal.extra.hu/books/a_valasztojog.pdf (Downloaded 21 February 2014).

21 Magyar életrajzi Lexikon 1000-1990 - Molnár Kálmán, online: http://mek.oszk.hu/00300/00355/html/ ABC09732/10726.htm (Downloaded 18 March 2014).

22 The Tripartitum (The Customary Law of the Renowned Kingdom of Hungary in Three Parts) was a collection of 
cient principle of our constitution, hence the "pars potior et sanior" principle requires the dominance of the most distinguished and most reputable people concerning dignity and science instead of the dominance of the quantified majority. ${ }^{23} \mathrm{He}$ also perceived the principle of "vota ponderantur" behind the proposal, according to which principle votes are not to be counted but to be weighted. ${ }^{24}$ Molnár also emphasised that illiterate men could not have voted directly. Ten illiterate voters' votes would have been required to elect an elector who could have voted directly. 1,271,000 people would have had indirect suffrage and 2,618,500 could have vote directly. He pointed out that voting would have not been secret, hence the legislators were aimed at ensuring the fairness of the elections. Andrássy detailed this argumentation concerning the proposal. ${ }^{25}$ Sándor Berecz referred to Andrássy's proposal even in 1932. He considered it being preposterous that Gyula Andrássy submitted his bill one year after plural voting in Austria had been abolished. He merely agrees with that part of the bill's reasoning which states that electoral districts with differing population lead to hidden plural voting as well and this form of plural voting was to be found in several countries, even in Austria. ${ }^{26}$

Thirty years after the submission of Andrássy's bill, Andor Csizmadia lawyer, legal, public administrative and cultural historian referred to the same part of the Tripartitum as Kálmán Molnár. This part sounds as follows: "Should the people be divided into two fractions, the decision of the more sober and noble part is to be accepted. We shall consider as the more sober and noble part this one in which most distinguished and reputable people in science are." 27

A lawyer József Ajtay interpreted general suffrage in a very unique way. He stated that general suffrage would mean that all of those should have suffrage who are properly conscious members of the state and not that as many people as possible should have suffrage. In his point of view, only people who are morally, intellectually and materially suitable to take part in public affairs at least at a minimum level should have the right to vote and to be elected. He considered ensuring each social class taking part in public life according to their proportion in the society as the best solution. He stated that plural voting would be a logical consequence of this requirement, hence general and equal suffrage would lead to the rule of the mass. He shed light on the fact that on the one hand, plural voting was supported by John Stuart Mill, Johann Caspar Bluntschli and Paul Laband, but on the other hand Győző Choncha, Arthur Balogh, Gyula Isaák and Georg Jellinek opposed it. He also

customary law collected and completed by István Werbőczy in 1514. Although the Hungarian National Assembly had never adopted it, it became the part of the customary law of Hungary. See: MEZEY, Barna: Magyar jogtörténet, Budapest 2007, 39-40.

23 MOLNÁR, Kálmán: Magyar Közjog. Tudományos Gyűjtemény 103, Danubia - Pécs 1929, 434-435.; FERDINANDY, Gejza: A választói jog történeti fejlődése. 902, online: http://mtdaportal.extra.hu/ADATTAR/cikktar/f_ cikk/ferdinandy_geza_a_valasztoi_jog_torteneti_fejlodese.pdf (Downloaded 9 November 2014).

24 MOLNÁR, Magyar Közjog, 435; Magyar Katolikus Lexikon- Országgyűlés, online: http://lexikon.katolikus. hu/O/orsz\%C3\%A1ggy\%C5\%B11\%C3\%A9s.html (Downloaded 9 November 2014).

25 MOLNÁR, Magyar Közjog, 435.

26 BERECZ, 73-74, 47, 56.

27 CSIZMADIA, Andor: A magyar választójog alakulása. Különlenyomat a Katolikus szemle 1938. évi augusztusi számából, 1.; WERBŐCZY, István: Tripartitum (1514.). Az ország jogainak és szokásainak harmadik részéről általában. 2. cím 8. §. 
summarized the opposite opinions considering plural voting. According to those who were against plural voting, it does not simply balance the effects of general suffrage, but terminates general suffrage. They declared that general suffrage has to be necessarily equal, hence human rights have to prevail not only in theory but also in practice. Ajtay stated that those scholars were wrong, since they considered equality of voting and equality of gaining representation as the same thing. He additionally argued that ensuring equality of voting would lead to incommensurate and unequal representation of different social classes. ${ }^{28}$ He criticised the fact that Andrássy's bill contained merely an intellectual census (literacy) concerning direct suffrage. He stated that literacy is one of the most evitable criteria of suffrage and that certification of certain level of education would be much proper. He explicitly declared that he considered the dominance of ethnic Hungarians to be maintained. $\mathrm{He}$ also criticized that the proposal would have given suffrage even to members of lower social classes, and it would have led to the increase of their influence, which opposed the intention of the legislators. His opinion was that this proposal would not have ensured the dominance of ethnic Hungarians and upper social classes although it was contested mostly by socialists and minorities whom sensitivity had been considered during the preparation of the bill. ${ }^{29}$

\section{Hidden Plural Voting as a Balance of Secret Ballot Voting}

Dual voting emerged again as a popular issue in the 1930s. Móric Tomcsányi, lawyer, university lecturer and member of the Hungarian Academy of Sciences ${ }^{30}$ pointed out in his book "Public Law of Hungary" that although several states (e.g. Belgium and France) experimented with plural voting, in the days of writing of his book (in 1932) nowhere could be found an electoral law stipulating plural voting. (Although plural voting was terminated in France merely two years before the publication of his book.) He stated that plural voting is considered to be a balance of general suffrage and it is not compatible with democratic principles. In addition, he found that definition of abilities and skills required to be entitled to cast multiple votes would be rather difficult. ${ }^{31}$

Béla Túri, Member of the Parliament ${ }^{32}$ declared in one of his writings in 1934 that secret ballot voting became an inevitable part of all of the modern states' life and it has to be realized even if several people grievously misuse it. In his point of view, it is not permitted trying to balance the dangers of it with different tricks, for the sake of the issue's real settlement. He held such a reform desirable which contains guarantees against the expansion of extremist movements in itself, without any tricks. ${ }^{33}$ However, Tihamér Acsay ${ }^{34}$ thought that

28 AJTAY, József: A választójogi reform, Budapest - Kilián 1908, 49-60.

29 Ibidem,123-132.

30 Magyar Életrajzi Lexikon 1000-1990 - Tomcsányi Móric, online: http://mek.oszk.hu/00300/00355/html/ ABC15363/15818.htm (Downloaded 18 March 2014).

31 TOMCSÁNYI, Móric: Magyarország közjoga, Budapest 1932, 389.

32 Magyar Katolikus Lexikon - Túri Béla, online: http://lexikon.katolikus.hu/T/T\%C3\%BAri.html (Downloaded 8 December 2014).

33 TÚRI, Béla: Milyen választójogi reformra van szükség? in: Katholikus Szemle, 1934, 582.

34 Magyar Életrajzi Lexikon - Acsay Tihamér, online: http://mek.oszk.hu/00300/00355/html/ABC00003/00074. 
plural voting is necessary to ensure a balance of secret ballot voting even if it is not sufficient enough to balance institutionally the decrease of electoral standards, merely making it less frequent. ${ }^{35}$

An inter-party conference was summoned by Prime Minister Kálmán Darányi which took place between 2 and 4 December 1936. This conference was aimed at discussing the main questions concerning suffrage. ${ }^{36}$ One of these questions was whether they should expand or tighten the active suffrage at the same time with the introduction of secret ballot voting. Béla Ivády, member of the Party of National Unity declared that they consider secret ballot voting as unrealizable until no guarantees ensuring the protection of our thousand year old and historically evolved constitution are established. Tibor Eckhardt, member of the Independent Smallholders', Agrarian Workers' and Civic Party found secret ballot voting dangerous hence it increases the role of demagogy and plutocracy. He emphasised that according to the general opinion, the balances intended to introduce are aimed at ensuring the leading role of intelligentsia during the fulfilment of the electoral reform. The Christian socialist politician, Tivadar Homonnay held such balances necessary based on similar grounds as well. If we move to the point of view of the social democrat politician Károly Peyer, it comes to light that his party had been fighting for general and equal suffrage and secret ballot voting for decades by that time. They found plural voting unacceptable as a consequence of this fact. At the same time, they agreed with balances of secret ballot voting as like as the Parliament's upper house's reform and broadening the Governor's competences. He stated that these balances would be sufficient precautionary measures against the expansion of far-right or far-left powers. The ex-Prime Minister István Bethlen emphasised that suffrage can be strengthened only until it does not endanger the high quality of the legislation and the establishment of a strong government. His standpoint was that incremental evolution of suffrage is necessary, and he did not oppose secret ballot voting. He noted that there is no option to decrease the number of people having active suffrage essentially and that politically uneducated people must be prevented from gaining power in public life at the same time. In spite of that István Friedrich stated, that secret ballot voting would not endanger the quality of the legislation. The legitimist ${ }^{37}$ Hugó Payr's point of view was that in such areas, where secret ballot voting had been introduced in Hungary, no disadvantages came to light regarding to it. The conservative Miklós Kállay's opinion was that secret ballot voting shall be enacted honestly and without any hidden intentions, but at the same time balances ensuring the sustainability of the nation and the state shall be enacted. Kálmán Darányi agreed with all of those people who found desirable that some balances aimed at ensuring fair elections and struggle against demagogy shall be ensured by the law. He declared that he is intended to ensure such balances in the electoral bill he would submit to the Parliament. ${ }^{38}$

József Ajtay emphasised that plural voting is generally considered being a means to the htm (Downloaded 8 December 2014).

35 ACSAY, Tihamér: Lajstromos szavazás egyéni választással. A választójog kérdései, Budapest 1934, 177-182.

36 ALBRECHT, Ferenc: A kormányzói jogkör kiterjesztése, in: Az ország útja (1937), I. évf. 2. szám 17.

37 Legitimists were royalists who supported the restauration of Habsburg dynasty in Hungary.

38 KRIVOSS, Árpád: Választójog, népesség, adóteher. Gazdaságpolitikai alapon készült választójogi tervezet, Budapest 1937, 33-54. 
mitigation of the "disadvantageous circumstances" caused by general and secret suffrage. After measuring the possibilities, he supported hidden plural voting of a necessary extent in the actual historical moment. ${ }^{39}$ The public lawyer and legal academy teacher ${ }^{40}$ Béla Zsedényi wrote a book on the three main constitutional law reforms of 1937 and 1938. Act 19 of 1938 was one of the laws analysed and evaluated by him. This law ensured secret ballot voting. It decreased the number of citizens entitled to vote, and ensured hidden plural voting at the same time as a balance. It increased the number of MPs from 245 to 260. 135 of them were elected in single member constituencies, further 125 MPs had been elected in a proportional system on a list. Although the preceding electoral law contained rules concerning eleven electoral districts based on proportional system as well, in which forty-six MPs had been elected, there was a big difference between the two acts. The new act established the so-called county lists. All of these lists covered more single member constituencies. More people could vote on a party list than on candidates in single member constituencies. 79 MPs were elected on county lists. As a consequence of all of this, voters entitled to vote on single candidates and county lists as well had multiple votes compared to others. In Zsedényi's point of view, this proposal was the only which could make us concern among the three reform acts due to the mixed electoral system, introduction of plural voting and complicated definition of the suffrage's preconditions. ${ }^{41}$ The other two reform acts were connected to broadening the scope of competence of the Parliament's Upper House ${ }^{42}$ and the Governor. ${ }^{43}$ All of these three reforms were aimed at preventing far-right groups from gaining power. ${ }^{44}$

Kálmán Molnár declared that the different condition of suffrage in different constituencies would not be easily justifiable. ${ }^{45}$ Ödön Polner, a public lawyer, university teacher and member of the Hungarian Academy of Sciences ${ }^{46}$ and László Ferdinandy, the son of the legal historian Gejza Ferdinandy supported plural voting but not its hidden form. ${ }^{47}$ Nowadays it may sound strange, but in Polner's point of view if they had had ensured suffrage to married women it would have meant the plural voting of their husband in practice and in the event it would have not, it would have distracted the peaceful family life. ${ }^{48}$ If we examine the results of the general election of 1939, we can see that concerns which led to the adop-

39 AJTAY, József: A helyes választójog ..., 18-23.

40 Magyar Életrajzi Lexikon 1900-1990 - Zsedényi Béla, online: http://mek.oszk.hu/00300/00355/html/ ABC17155/17378.htm (Downloaded 18 March 2014).

41 ZSEDÉNYI Béla: A magyar alkotmányjog fejlődése 1918-tól 1938-ig, 37. szám, Miskolc 1939, 8-10; Act 19 of 1938 19-22. §.

42 MOLNÁR, Kálmán: Alkotmányjogi reformjaink az 1937 és 1938 években, Pécs 1938, 31-32.

43 Ibidem, 15-30.

44 PÜSKI, Levente: Választási rendszer és parlamentarizmus a Horthy-korszakban, in: A magyar jobboldali hagyomány 1900-1948, ROMSICS Ignác (ed.), Budapest 2009, 93-94.

45 MOLNÁR, Kálmán: Alkotmányjogi... 52.

46 Magyar Életrajzi Lexikon 1000-1990 - Polner Ödön, online: http://mek.oszk.hu/00300/00355/html/ ABC11587/12347.htm (Downloaded 18 March 2014).

47 POLNER, Ödön: A titkos szavazásos választójogi törvényjavaslat, Szeged 1938, 6-9.

48 Ibidem, 16; FERDINANDY, László: A választójogi törvényjavaslat kritikája. Előadás a Deák Ferenc Társaságnak 1938. január 18-i ülésén, 4-11. 
tion of Act 19 of 1938 did not emerge without a reason. Anti-system parties ${ }^{49}$ achieved 6\% percent more votes in proportional constituencies where the number of people eligible to vote was higher $(2,761,618)$ than in single member constituencies where less people had the right to vote..$^{50}$ We can definitely state that the above mentioned two forms of plural voting would not be acceptable in a democratic state under the rule of law. In addition, it would not be easy to define the conditions of casting multiple votes. In the next section we will examine whether plural voting in a democratic state can exist nowadays or not, and if it can, how it is connected to the issue of national minorities.

\section{Plural Voting and Ethnic Minorities Representation Nowadays}

The Venice Commission declared plural voting as an unacceptable institution violating the equality of suffrage. According to their point of view the equality of suffrage means that each voter can cast the same amount of votes and their votes have the same weight. Furthermore, equality of opportunity has to be ensured during voting. This opinion contained statements concerning the equality of minorities' suffrage as well. The Commission emphasised that electoral law is required to be non-discriminatory with regard to minorities and electoral rules shall guarantee the equality of suffrage of people belonging to a minority coping with the international public law's rules. They declared that ethnic minority parties shall not be banned and they prohibited the change of electoral districts' barriers or the parliamentary threshold in a way which means a legal impediment of the minorities' representation in elected bodies. They find it acceptable if certain countries maintain some separate parliamentary mandates to member of minorities or giving them any exemption from the general electoral rules. They even give an exemption from the one man-vote principle. If the circumstances require, it could be allowed even that voters belonging to national minorities are entitled to vote both on a party list and a minority list which means plural voting. They also declared that neither candidates nor voters may be forced to disclose their ethnicity. ${ }^{51}$ The Commission adopted a separate opinion on the representation of minorities as well. ${ }^{52}$

Another report was made on the dual voting of voters belonging to national minorities. There is only one country which ensures plural voting to persons belonging to certain minority. This country is Slovenia. The Commission emphasised that no general consequences may be derived from this opinion. As a consequence of that, it has to be considered in each single case whether ensuring plural voting to minorities would be necessary and

49 Arrow Cross Party, Social Democratic Party of Hungary, non-partisan far-right, Christian National Socialist Front, National Front, United Hungarian National Socialist Party, Hungarian National Socialist Agricultural Labourers' and Workers' Party, non-partisan racist ("national defense"), Party of National Will, United Hungarian National Socialist Party

50 HUBAI, László: Magyarország XX. századi választási atlasza 1920-2000, CD-ROM, Budapest 2001.

51 Venice Commission Opinion No. 190/2002. Code of good practice in electoral matters. Guidelines and explanatory report pp.16-20, online: http://www.venice.coe.int/webforms/documents/?pdf=CDL-AD(2002)023-e (Downloaded 28 February 2014).

52 Venice Commission - Study on electoral law and national minorities, in: Electoral law, CDL-EL(2013)006, 44-100, online: http://www.venice.coe.int/webforms/documents/?pdf=CDL-EL(2013)006-e (Downloaded 2 March 2014). 
proportionate compared to the aim. ${ }^{53}$ This regulation worths to be examined in the latter. Dual voting is very rare in the modern western world. As it came to light, Slovenia is the only European country which applies this institution. Slovenia has a bicameral Parliament. Ninety members of the lower house of the Slovenian legislation (the National Assembly) are elected to four-year electoral cycle. Eighty-eight of the MPs are elected in eleven constituencies, based on a proportional system and with the application of a $4 \%$ parliamentary threshold. Two special constituencies were established for the members of the autochthonous Italian and Hungarian minorities. One seat can be obtained in both of these constituencies. ${ }^{54}$ As we could see, ethnic Italians and Hungarians living in Slovenia have privileged parliamentary representation, although their communities reach merely a few thousands of population. ${ }^{55}$ Italian and Hungarian voters can cast preferential votes in their special electoral constituencies. In these two constituencies Borda count is used. ${ }^{56}$

More than $80 \%$ percent of Slovenia's inhabitants is ethnic Slovenian. This proportion is $90 \%$ according to Robert Győri Szabó. The census of 2002 shows that $83.3 \%$ of the inhabitants is ethnic Slovenian, the ethnicity of $6.43 \%$ is unknown and $2.47 \%$ of the people did not want to answer any questions concerning their ethnicity. Slovenia's two constitutionally acknowledged minorities are the ethnic Italians and the ethnic Hungarians. ${ }^{57}$ Although most of their minority rights are ensured to them only in the territory of the settlements inhabited by them, there are two exceptions. On one hand, members of these communities, who attend at secondary school, are entitled to learn in their mother tongue in any secondary school of Slovenia if their number exceeds a certain level. On the other hand, they are entitled to elect a minority representative to the National Assembly wherever they live in Slovenia. ${ }^{58}$ A permanent Minority Committee has to be established in the National Assembly in each electoral cycle. The two minority representatives are ex lege members of this committee. ${ }^{59}$ The Venice Commission's opinion on the European minorities' participation

53 Venice Commission - Study No. 387/2006. CDL-AD(2008)013. Report on dual voting for persons belonging to national minorities, online: http://www.venice.coe.int/webforms/documents/CDL-AD\%282008\%29013.aspx (Downloaded 19 March 2014).

54 IPU PARLINE database: Slovenia Drzavni Zbor (National Assembly), online: http://ipu.org/parline-e/reports/2287.htm (Downloaded 8 March 2014).

55 HALÁSZ, Iván: Nemzeti és etnikai kisebbségek és a kisebbségi jogi szabályozások Közép-Európában, in: Kisebbségkutatás, 16, 2007, 3, online: http://epa.oszk.hu/00400/00462/00035/cikk45e5.html (Downloaded 8 March 2014).

56 SZENTPÉTERI-NAGY, Richard: Választások Szlovéniában, in: Választójog és választási rendszerek. Öt közép-európai ország parlamenti választási törvénye. Választási stúdiumok 1, DEZSŐ, Márta (ed.), Budapest 1998, 314.

57 GYŐRISZABÓ, Róbert: Kisebbségpolitika Szlovéniában: a magyar és az olasz közösség autonómiája, in: Kisebbségkutatás, 17, 2008, 1, online: http://epa.oszk.hu/00400/00462/00037/1532.htm (Downloaded 8 March 2014); GYŐRI SZABÓ, Róbert: A szlovéniai magyar és olasz kisebbség autonómiája, politikai képviselete, in: Nemzetfogalmak és etnopolitikai modellek Kelet-Közép-Európában, SZARKA, László et.al., Budapest 2007, 311-314; Census 2002: 7. Population by ethnic affiliation, Slovenia, Census 1953, 1961, 1971,1981,1991 and 2002. Statistical Office of the Republic of Slovenia, online: http://www.stat.si/popis2002/en/rezultati/rezultati_red.asp?ter=SLO\&st=7 (Downloaded 8 March 2014).

58 DEVETAK, Silvo: Autonomy as one of the means of minorities protection - the case of Slovenia, Cited by: GYÖRI SZABÓ: Kisebbségpolitika...

59 CALIC, Marie-Janine: Nationalitätenfragen und Minderheitenpolitik in Slowenien, in: Minderheiten im östlichen Mitteleuropa, BRICKE, W. Dieter, Baden-Baden 1995, 178. Cited by: GYŐRI SZABÓ; MARKO, Joseph: 
in decision-making gives us some more detailed information. It is stipulated in Article 64 of the Slovenian Constitution that representation of Italian and Hungarian minorities shall be ensured both on a national and on a local level. Article 80 declares that it always has to be guaranteed that members of each of the two minorities can elect to the National Assembly not only a representative, but a special minority representative as well. So we can see, that the political representation and even the plural voting of the Italian and Hungarian minorities living in Slovenia are ensured constitutionally. The report emphasises that dual voting is ensured to voters belonging to these groups; hence they can cast a vote in both types of constituencies. The document also mentions that the Slovenian electoral law stipulates that a separate electoral council has to be established to the election of their representatives in their special constituencies. ${ }^{60}$ Minority candidates shall be non-partisan. ${ }^{61}$ It is constitutionally ensured that no laws or other legislative measures concerning minorities may be adopted without the vote of the two minority representatives. That means that they have a right to raise a veto concerning measures of the legislation which are connected to them. ${ }^{62}$ These electoral rules are often challenged by members of other minorities living in Slovenia but being not declared as autochthonous minorities. Such groups are for example ethnic Croatians and Serbians who are mainly considered as migrants, but in practice they have been living there for more than one hundred years. Nevertheless, their population is bigger than the Italian and Hungarian population living in Slovenia. ${ }^{63}$

The Constitutional Court of Slovenia examined the parliamentary representation of the two minorities as well. The Court ruled that it is not unconstitutional that the law on the parliamentary elections ensures two votes - a general and a special one - to the members of the two communities. It has been declared that the special suffrage of these persons is the manifestation of the minority communities' and their members' constitutional protection. They considered this legal institution as acceptable in spite of the fact that it means a difference from the principle of equal suffrage. Moreover, they pointed out that such a positive discrimination is not merely compatible with the Constitution, but it is a constitutionally stipulated obligation. They examined as well whether the minorities' representation could be accomplished in any differing way or not. Their standpoint is, that if minority voters ought to choose between the exercise of the general and the special suffrage, they would be deprived from one of their constitutionally ensured rights, which means that such rules would cause an unconstitutional situation. ${ }^{64}$

Der Minderheitenschutz in den jugoslawischen Nachfolgestaaten. Bonn 1996, 131. Cited by: GYÖRI SZABÓ: Kisebbségpolitika...

60 Venice Commission - Report on electoral rules and affirmative action for national minorities' participation in decision-making process in European Countries, in: Electoral law. CDL-EL (2013)006 95, online: http://www. venice.coe.int/webforms/documents/?pdf=CDL-EL(2013)006-e (Downloaded 2 March 2014).

61 BOCHSLER, Daniel: Electoral Rules and the Representation of Ethnic Minorities in Post-Communist European Democracies, in: Yearbook of Minority Issues, 8, 2007, 7, 153-180.19, online: http://www.bochsler.eu/publi/ Bochsler_eymi_edit1.pdf (Downloaded 8 March 2014).

62 PETRICUSIC, Antonija: Slovenian Legislative System for Minority Protection, 5-6, online: http://www6.gencat.cat/llengcat/noves/hm04tardor/docs/petricusic.pdf (Downloaded 8 March 2014); PAP, András László: Identitás és reprezentáció. Az etnikai hovatartozás meghatározásától a politikai képviseletig, Budapest 2007, $210-211$.

63 ALIONESCU, Ciprian-Calin: Parliamentary Representation of Minorities in Romania, in: Southeast European Politics, Vol. V, 2004, 1, 62, online: http://www.seep.ceu.hu/archives/issue51/alionescu.pdf (Downloaded 8 March 2014).

64 Case U-I-283/94. of 12 February 1998 (Constitutional Court of Slovenia), online: http://odlocitve.us-rs.si/usrs/ 


\section{Parliamentary Representation of National Minorities in Hungary}

Although a claim for the parliamentary representation of national minorities had been occurring since the change of regime, ${ }^{65}$ it has been ensured to thirteen acknowledged national minorities living in Hungary only by the adoption of the Act 203 of 2011. No plural vote is ensured to the members of minorities. They can vote on an individual candidate and on a national list. National lists may be party lists or minority lists set by the National Minority Self-Governments. Voters aiming to vote on a minority list have to register as a minority voter. One preferential seat can be obtained on each minority list reaching a preferential threshold. The general threshold has to be reached to the gaining of every other seats. Shall the votes cast on the minority list be too few to gain a preferential seat, the first person on the list represents the minority as a minority spokesperson. ${ }^{66}$ Minority spokespersons have weaker competences than MPs. ${ }^{67}$ More scholars turned their attention to the fact that members of the national minorities do not have much chance to gain even one preferential seat. ${ }^{68}$ Erzsébet Szalayné Sándor, the vice ombudsman for minority protection even stated before the general elections of 2014 that the regulation changes the one manone vote principle to the principle "one minority voter - half vote", which means that the

us-odl.nsf/o/63D0F88CC8BF4EB6C12571720028092A (Downloaded 18 March 2014).

65 DOBOS, Balázs: A kisebbség joga. Kisebbségi törvénykezés Magyarországon (1988-2006). Argumentum, MTA Etnikai-nemzeti Kisebbségkutató Intézete, Budapest 2011, 168-170.; PAP, Identitás és reprezentáció, 233245.; MAJTÉNYI, Balázs: Félreértett jogosultságok. Bizonytalan helyzetű alapjogok Magyarországon. Budapest 2010, 92-94.

66 Act 203 of 2011 on the election of the Members of the Parliament 7-10.§, 16.§, 18.§;

BERTA, Zsolt - CSERNY, Ákos - SÁRI, Miklós - SZABLICS, János: Kommentár az országgyűlési képviselők választásáról szóló 2011.évi CCIII. törvényhez, in: Választójogi kommentárok, CSERNY, Ákos (ed.), Budapest 2014, 33-35, 41-44. For additional information on the representation of national minorities in Hungary and its further aspects see: KURUNCZI, Gábor: On the issue of the representation of nationalities in the Parliament, in: Hungarian Yearbook of International Law and European Law 2014, LÁNCOS, Petra Lea - VARGA, Réka - MOLNÁR, Tamás - SZABÓ, Marcel (eds.), The Hague 2015, 507-523.; ERDŐS, Csaba: Multiculturalism in the Hungarian Parliamentary Law: Questions Concerning the Parliamentary Representation of Nationalities, in: Multiculturalism and Contemporary Society, ZIVKOVIC Milan (ed.), Conference University of Novi Sad, Faculty of European Legal and Political Studies, Szerbia 1 March 2013, Novi Sad 2013, 332-346.; PAP, András László: Sarkalatos Átalakulások. A nemzetiségekre vonatkozó szabályozás, in: MTA Law Working Papers, 2014, 52, online: http://jog.tk.mtahu/uploads/files/mtalwp/2014_52_Pap.pdf (Downloaded 18 October 2016);. PAP, András László: Észrevételek a nemzetiségek parlamenti képviseletének szabályozásához az Alaptörvényben, a választójogi törvényben és a nemzetiségek jogairól szóló törvényben, in: Alkotmányozás Magyarországon 2010-2011, JAKAB András - DRINÓCZI Tímea (eds.), Budapest - Pécs 2013, 419-438.; CHRONOWSKI, Nóra: Alaptörvény és etnicitás - avagy az alkotmányozás viharaiban részekre szakadt nemzetünk, in: Állam és Jogtudomány, LVIII. évfolyam, 2015,1, 3-18. MÓRÉ, Sándor: A nemzetiségek országgyúlési képviseletének egyes kérdései Magyarországon, in: Magyar Jog, $2015,10,584-592$.

67 Act 36 of 2012 on the National Assembly 22. §, 29-29/A. §.

68 BALÁZS, Ágnes: Plurális választójog és nemzetiségek Európában. OTDK dolgozat. Budapest 2014.; KURUNCZI, Gábor: A nemzetiségek parlamenti képviseletének kérdéséről, in: Pázmány Law Working Papers, 2013,14, online: http://d18wh0wf8v71m4.cloudfront.net/docs/wp/2013/2013-14-Kurunczi.pdf (Downloaded 30 April 2016).; SZALAYNÉ SÁNDOR, Erzsébet: Magyarországi nemzetiségi választások. Kisebbségkutatás. 23. évf. 2014, 1, 13.; ERDŐS, Csaba: A Problematic Part of the Renewed Hungarian Parliamentary Law: The Parliamentary Representation of Nationalities, in: De lurisprudentia et lure Publico: Jog- és Poltikatudományi Folyóirat. VII. évfolyam, 2013, 1. 5. see also: KURUNCZI, Gábor: A nemzetiségek parlamenti képviseletének kérdéséről, in: Közjogi Szemle, 2014, 1, 56-65. 
regulation's effect is totally different from its aim what was ensuring a preferential mandate to minority voters. ${ }^{69}$ The outcome of the 2014 election showed us, that their concerns have not been unfounded..$^{70}$ That is why it is worth examining in a future paper how these rules could be corrected and whether the regulation of Slovenia or other neighbouring countries could serve as a model for Hungary or not. And if not, how the rules concerning minorities' parliamentary representation could be improved.

\section{Conclusion}

As we could see, the issue of plural voting was an important issue in the first half of the $20^{\text {th }}$ Century in Hungary. More scholars of public law favoured this institution than opposed it. We could see as well that other European countries applied plural voting at this time as well. It also came to light that the proposal of Gyula Andrássy filed to the Parliament in 1907 declared plural voting in a direct way and was aimed at preventing national minorities from gaining power. The Act 19 of 1938 introduced a hidden form of dual voting by different definition of voters in two different type of constituencies. After that plural voting was not applied in Hungary anymore. Although these regulations could not be accepted in a democratic state under the rule of law, plural voting is not absolutely prohibited all around Europe at all. The Venice Commission considers the equality of suffrage as a non-absolute right, and it supports preferential representation of minorities as well. They declared connected to these two facts that dual voting is a necessary and proportional means of ensuring the parliamentary representation of Italian and Hungarian autochthonous minorities in Slovenia, so it is not an unjustified violation of the equal suffrage principle. At the same time they emphasised that no general rules may be derived from the case of Slovenia. As a consequence of that it has to be examined case-by-case whether such a measure would be necessary to fulfil the aim, and proportional to it. It was outlined as well that suffrage of national minorities may be diminished by the Hungarian statute currently in effect; thus, they are entitled to vote either on a nationality list, or a party list and due to their number they do not have a real chance to elect an MP from a minority list, hence they have no impact on seats to be obtained by candidates on a national list and only a minority spokesperson having less rights than MPs represent them in the National Assembly. This situation is different from the case when votes cast on a certain party list do not meet the parliamentary threshold. In latter case, voters have a theoretical chance to influence the person of MPs by voting on a party list as well, while minority voters do not even have a chance to do that, hence we could foresee that candidates on minority lists barely could obtain any seats in our legislation. It is worth examining it later whether Slovenia or any other neighbouring countries could serve as a model for the improvement of the Hungarian minorities' parliamentary representation, or we should design a totally new system.

69 SZALAYNÉ, 13.

70 BALÁZS, Ágnes: A választójog egyenlősége. Dilemmák és határesetek. Budapest 2015, 24-26. 


\begin{abstract}
In this paper the relationship between parliamentary representation of nationalities and plural voting in Europe will be examined. First of all, it will be overviewed which European countries applied plural voting before 1945. Then the Hungarian legal scientists' judgement of multiple voting before 1945 will be described and we ascertain when the Hungarian decision-makers intended to enact plural voting and how is it connected to minority issues. The Venice Commission's opinion on the topic will also be detailed according to which plural voting is admissible only if it is in relation with representation of minorities and for the benefit of them. After this historical and theoretical overview, the practice of the only European country - Slovenia - applying plural voting on such a basis will be described. This paper also relates to the problem of plural voting and nationality in Hungary. The system of parliamentary representation of ethnic minorities in Hungary will be shortly analysed as well.
\end{abstract}

\title{
Keywords
}

plural voting, minorities, minority rights, representation of minorities, suffrage

\section{References}

Venice Commission Opinion No. 190/2002. Code of good practice in electoral matters. Guidelines and explanatory report, online:

http://www.venice.coe.int/webforms/documents/?pdf=CDL-AD(2002)023-e (Downloaded 28 February 2014).

Venice Commission - Report on electoral rules and affirmative action for national minorities' participation in decision-making process in European Countries, in: Electoral law, CDL-EL(2013)006, online:

http://www.venice.coe.int/webforms/documents/?pdf=CDL-EL(2013)006-e (Downloaded 2 March 2014).

Venice Commission - Study No. 387/2006. CDL-AD(2008)013. Report on dual voting for persons belonging to national minorities, online:

http://www.venice.coe.int/webforms/documents/CDL-D\%282008\%29013.aspx (Downloaded 19 March 2014).

Venice Commission - Study on electoral law and national minorities, in: Electoral law. CDL-EL(2013)006, online: http://www.venice.coe.int/webforms/documents/?pdf=CDL-EL(2013)006-e (Downloaded 2 March 2014).

Act 19 of 1938 on the Election of the Members of the Parliament Act 203 of 2011 on the Election of the Members of the Parliament Act 36 of 2012 on the National Assembly 
Case U-I-283/94. of 12 February 1998 (Constitutional Court of Slovenia), online: http://odlocitve.us-rs.si/usrs/us-odl.nsf/o/63D0F88CC8BF4EB6C12571720028092A (Downloaded 18 March 2014).

Census 2002: 7. Population by ethnic affiliation, Slovenia, Census 1953, 1961, 1971, 1981, 1991 and 2002. Statistical Office of the Republic of Slovenia, online:

http://www.stat.si/popis2002/en/rezultati/rezultati_red.asp?ter=SLO\&st=7 (Downloaded 8 March 2014).

IPU PARLINE database: Slovenia Drzavni Zbor (National Assembly), online: http://ipu.org/parline-e/reports/2287.htm (Downloaded 8 March 2014).

Magyar Életrajzi Lexikon - Acsay Tihamér, online: http://mek.oszk.hu/00300/00355/html/ABC00003/00074.htm (Downloaded 8 December 2014).

Magyar Életrajzi Lexikon 1000-1990 - Hieronymi Károly, online: http://mek.oszk.hu/00300/00355/html/ABC05727/06328.htm (Downloaded 18 March 2014).

Magyar Életrajzi Lexikon 1000-1990 - Márkus Dezső, online: http://mek.oszk.hu/00300/00355/html/ABC09732/10071.htm (Downloaded 18 March 2014).

Magyar Életrajzi Lexikon 1000-1990 - Molnár Kálmán, online: http://mek.oszk.hu/00300/00355/html/ABC09732/10726.htm (Downloaded 18 March 2014).

Magyar Életrajzi Lexikon 1000-1990 - Polner Ödön, online: http://mek.oszk.hu/00300/00355/html/ABC11587/12347.htm (Downloaded 18 March 2014).

Magyar Életrajzi Lexikon 1000-1990 - Réz Mihály, online: http://mek.oszk.hu/00300/00355/html/ABC12527/12993.htm (Downloaded 18 March 2014).

Magyar Életrajzi Lexikon 1000-1990 - Tomcsányi Móric, online: http://mek.oszk.hu/00300/00355/html/ABC15363/15818.htm (Downloaded 18 March 2014).

Magyar Életrajzi Lexikon 1900-1990 - Zsedényi Béla, online: http://mek.oszk.hu/00300/00355/html/ABC17155/17378.htm (Downloaded 18 March 2014).

Magyar Katolikus Lexikon - Országgyülés, online: http://lexikon.katolikus.hu/O/orsz\%C3\%A1ggy\%C5\%B1/\%C3\%A9s.html (Downloaded 9 November 2014).

Magyar Katolikus Lexikon - Túri Béla, online: http://lexikon.katolikus.hu/T/T\%C3\%BAri.html (Downloaded 8 December 2014).

ACSAY, Tihamér: Lajstromos szavazás egyéni választással. A választójog kérdései, Budapest 1934. 
AJTAY, József: A választójogi reform, Budapest-Kilián 1908.

AJTAY, József: A helyes választójog követelményei, in: Az ország útja, 1937, I. évfolyam, 10. szám.

ALBRECHT, Ferenc: A kormányzói jogkör kiterjesztés, in: Az ország útja, 1937, I. évfolyam, 2. szám.

ALIONESCU, Ciprian-Calin: Parliamentary Representation of Minorities in Romani, in: Southeast European Politics, Vol. V, 1, June 2004, online: http://www.seep.ceu.hu/archives/issue51/alionescu.pdf (Downloaded 8 March 2014).

ÁCS, Nándor: A magyar választási rendszer főbb változásai 1848-től 1989-ig, in: Ünnepi tanulmányok Rácz Attila 75. születésnapja tiszteletére, CSERNY, Ákos (ed.), Budapest 2013, 19-40.

BALÁZS, Ágnes: Plurális választójog és nemzetiségek Európában. OTDK dolgozat, Budapest 2014.

BALÁZS, Ágnes: A választójog egyenlősége. Dilemmák és határesetek, Budapest 2015.

BARNETT, Hilarie: Constitutional \& Admininstrative Law, Abingdon 2013.

BARTOLINI, Stefano: The Political Mobilization of the European Left, 1860-1890. The Class Cleavage, New York 2000.

BERECZ, Sándor: A tökéletes választójog, Budapest 1932.

BERTA, Zsolt - CSERNY, Ákos - SÁRI, Miklós - SZABLICS, János: Kommentár az országgyűlési képviselők választásáról szóló 2011.évi CCIIl. törvényhez, in: Választójogi kommentárok, CSERNY, Ákos (ed.), Budapest 2014, 15-48.

BOCHSLER, Daniel: Electoral Rules and the Representation of Ethnic Mionorities in Post-Communist European Democracies, in: Yearbook of Minority Issues, 2007, 8, 7, 153180, online: http://www.bochsler.eu/publi/Bochsler_eymi_edit1.pdf (Downloaded 8 March 2014).

CALIC, Marie-Janine: Nationalitätenfragen und Minderheitenpolitik in Slowenien, in: Minderheiten im östlichen Mitteleuropa, BRICKE, W. Dieter, Baden Baden 1995. Cited by: GYÖRI SZABÓ

CHRONOWSKI, Nóra: Alaptörvény és etnicitás - avagy az alkotmányozás viharaiban részekre szakadt nemzetünk, in: Állam és Jogtudomány, LVIII. évfolyam, 2015, 1, 3-18.

CSIZMADIA, Andor: A magyar választójog alakulása. Különlenyomat a Katolikus szemle 1938. évi augusztusi számából.

DEVETAK, Silvo: Autonomy as one of the means of minorities protection - the case of Slovenia, Cited by: GYÖRI SZABÓ: Kisebbségpolitika...

DOBOS, Balázs: A kisebbség joga. Kisebbségi törvénykezés Magyarországon (19882006), Budapest 2011.

ERDŐS, Csaba: A Problematic Part of the Renewed Hungarian Parliamentary Law: The Parliamentary Representation of Nationalities, in: De lurisprudentia et lure Publico: Jog- és Poltikatudományi Folyóirat, VII..évfolyam, 2013, 1, 51-61.

ERDŐS, Csaba: Multiculturalism in the Hungarian Parliamentary Law: Questions Concerning the Parliamentary Representation of Nationalities, in: Multiculturalism and Contemporary Society, ZIVKOVIC, Milan (ed.), Conference University of Novi Sad, Faculty of European Legal and Political Studies, Szerbia 1 March 2013, Novi Sad 2013, 332-346. FERDINANDY, Gejza: A választói jog történeti fejlődése., online: 
http://mtdaportal.extra.hu/ADATTAR/cikktar/f_cikk/ferdinandy_geza_a_valasztoi_jog_ torteneti_fejlodese.pdf (Downloaded 9 November 2014).

FERDINANDY, László: A választójogi törvényjavaslat kritikája. Elöadás a Deák Ferenc Társaságnak 1938. január 18-i ülésén. Az Athenaeum Rt. Nyomása.

GOLDSTEIN, Robert Justin: Political Repression in 19th Century Europe, London 1983.

GRIFFITH, J.A.G: Representation of the People Act. 1949, in: The Modern Law Review, 13, 3, 1950, 348-350.

GYŐRI SZABÓ, Róbert: A szlovéniai magyar és olasz kisebbség autonómiája, politikai képviselete, in: Nemzetfogalmak és etnopolitikai modellek Kelet-Közép-Európában. Tér és Terep 6, SZARKA, László et al., Budapest 2007, 308-323.

GYŐRI SZABÓ, Róbert: Kisebbségpolitika Szlovéniában: a magyar és az olasz közösség autonómiája, in: Kisebbségkutatás, 17. évf. 2008, 1, online: http://epa.oszk.hu/00400/00462/00037/1532.htm (Downloaded 8 March 2014)

HALÁSZ, Iván: Nemzeti és etnikai kisebbségek és a kisebbségi jogi szabályozások Közép-Európába, in: Kisebbségkutatás. 16. évf, 2007, 3, online: http://epa.oszk. hu/00400/00462/00035/cikk45e5.html Downloaded 8 March 2014).

HUBAI, László: Magyarország XX. századi választási atlasza 1920-2000, Budapest 2001.

KRIVOSS, Árpád: Választójog, népesség, adóteher. Gazdaságpolitikai alapon készült választójogi tervezet, Budapest 1937.

KURUNCZI, Gábor: A nemzetiségek parlamenti képviseletének kérdésérő, in: Pázmány Law Working Papers, 2013, 14, online: http://d18whOwf8v71m4.cloudfront.net/docs/wp/2013/2013-14-Kurunczi.pdf (Downloaded 30 April 2016).

KURUNCZI, Gábor: A nemzetiségek parlamenti képviseletének kérdéséről, in: Közjogi Szemle, 2014, 1, 56-65.

KURUNCZI, Gábor: On the issue of the representation of nationalities in the Parliament, in: Hungarian Yearbook of International Law and European Law 2014, LÁNCOS, Petra Lea VARGA, Réka - MOLNÁR, Tamás - SZABÓ, Marcel (eds.), The Hague 2015, 507-523.

LUCE, Robert: Legislative Principles: The History and the Theory of Lawmaking Representative Government, New Yersey 2006. Second printing 2007. Originally published: Boston Houghton Mifflin Co., 1930.

MAJTÉNYI, Balázs: Félreértett jogosultságok. Bizonytalan helyzetû alapjogok Magyarországon, Budapest 2010.

MARKO, Joseph: Der Minderheitenschutz in den jugoslawischen Nachfolgestaaten, Bonn 1996. Cited by: GYŐRI SZABÓ: Kisebbségpolitika...

MÁRKUS, Dezső: Választójog. A nő választójoga. Két tanulmány, Budapest 1912, online: http://mtdaportal.extra.hu/books/a_valasztojog.pdf (Downloaded 21 February 2014)

MEZEY, Barna: Magyar jogtörténet. Negyedik, átdolgozott kiadás, Budapest 2007. MOLNÁR, Kálmán: Magyar Közjog. Tudományos Gyújtemény 103, Danubia- Pécs 1929. MOLNÁR, Kálmán: Alkotmányjogi reformjaink az 1937 és 1938 években, Pécs 1938. MÓRÉ, Sándor: A nemzetiségek országgyúlési képviseletének egyes kérdései Magyarországon, in: Magyar Jog, 2015, 10, 584-592.

PAP, András László: Észrevételek a nemzetiségek parlamenti képviseletének szabályozásához az Alaptörvényben, a választójogi törvényben és a nemzetiségek jogairól 
szóló törvényben, in: Alkotmányozás Magyarországon 2010-2011, JAKAB, András - DRINÓCZI, Tímea (eds.), Budapest - Pécs 2013, 419-438.

PAP, András László: Identitás és reprezentáció. Az etnikai hovatartozás meghatározásától a politikai képviseletig. Budapest 2007.

PAP, András László: Sarkalatos Átalakulások. A nemzetiségekre vonatkozó szabályozás, in: MTA Law Working Papers, 2014, 52, online:

http://jog.tk.mta.hu/uploads/files/mtalwp/2014_52_Pap.pdf (Downloaded 18 October 2016).

PAPP, Imre: A politikai részvételi jogok, in: Emberi jogok, TÓTH, Gábor - HALMAI, Attila (eds.), Budapest 2003, 734-790.

PETRICUSIC, Antonija: Slovenian Legislative System for Minority Protection, online: http://www6.gencat.cat/llengcat/noves/hm04tardor/docs/petricusic.pdf (Downloaded 8 March 2014).

POLNER, Ödön: A titkos szavazásos választójogi törvényjavaslat. A Magyar Királyi Ferencz József Tudományegyetem Barátai Egyesületének Jog- és Államtudományi szakosztályában tartott elöadások 27. Szeged, 1938.

PÜSKI, Levente: Választási rendszer és parlamentarizmus a Horthy-korszakban, in: A magyar jobboldali hagyomány, 1900-1948, ROMSICS, Ignác (ed.), Budapest 2009, 73-101.

RÉZ, Mihály: A választói jogról, in: Választójog. Tanulmányok, TISZA, István et al., Budapest 1913, 41-53.

RÉZ, Mihály: Gróf Andrássy választójogi tervezete. in: Választójog. Tanulmányok, TISZA, István, et al., Budapest 1913, 80-89.

SZALAYNÉ SÁNDOR, Erzsébet: Magyarországi nemzetiségi választások, in: Kisebbségkutatás, 23. évf., 2014, 1, 7-14.

SZENTPÉTERI-NAGY, Richard: Választások Szlovéniában. In: Választójog és választási rendszerek. Öt közép-európai ország parlamenti választási törvénye. Választási stúdiumok 1, DEZSÖ, Márta (ed.), Budapest 1998, 303-321.

TISZA, István: Hieronymi a választójogról, in: Választójog. Tanulmányok, TISZA, István et al. Budapest 1913, 102-118.

TOMCSÁNYI, Móric: Magyarország közjoga. Második, átdolgozott és bővített kiadás, Budapest 1932.

TÚRI, Béla: Milyen választójogi reformra van szükség? in: Katholikus Szemle, October 1934, 581-585.

VÉRTES, István: 100 éves harc a választójogért, Budapest 1934.

WERBŐCZY, István: Tripartitum (1514). Az ország jogainak és szokásainak harmadik részérōl általában.

ZSEDÉNYI, Béla: A magyar alkotmányjog fejlődése 1918-tól 1938-ig, 37. szám, Miskolc 1939. 